Nig. J. Biotech. Vol. 36 (2) : 158-166 (Dec 2019)

ISSN: 01891731

Available online at

http://www.ajol.info/index.php/njb/index

and www.biotechsocietynigeria.org

DOI: https://dx.doi.org/10.4314/njb.v36i2.16

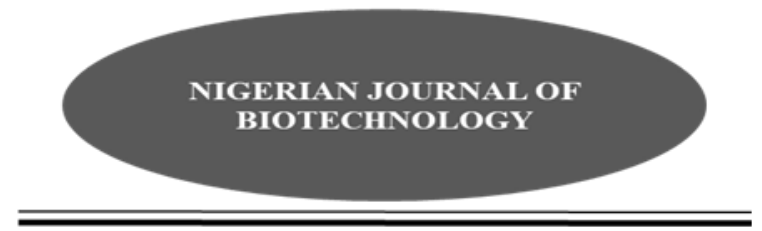

\title{
$16 S$ rDNA Sequencing analysis in identification of some multidrug resistant (MDR) bacterial isolates from clinical specimens
}

\author{
Iliyasu, M.Y1* , Bamanga, R.A ${ }^{2}$, Umar A.F ${ }^{1}$, Agbo, E.B1', and Uba, A $^{1}$ \\ ${ }^{1}$ Department of Microbiology, Abubakar Tafawa Balewa University, ATBU, Bauchi \\ 2Department of Biotechnology, Modibbo Adama University of Technology, Yola, Nigeria
}

\begin{abstract}
Accurate identification of bacterial pathogens from clinical specimens and Multidrug Resistant (MDR) characterization is a key to empirical therapy. Twelve (12) bacteria isolates from blood, urine and faecal samples were selected based on the ability to grow on Luria Bertani (LB) agar medium containing $100 \mu \mathrm{g} / \mathrm{ml}$ ampicillin, identified by 165 rDNA PCR and sequencing. Identified isolates tagged; U01, U02, U03, U04, S08, U10 and U11 were from urine specimens, S05, S06, S07 and S12 from stool, while B09 was from blood. The isolates were screened for MDR pattern according to Kirby-Bauer disc diffusion method. Conventional biochemical tests revealed that all the isolates are Escherichia coli. The $16 \mathrm{~S}$ gene sequencing results confirmed that, ten (10) isolates had high similar sequence alignment with identified $E$. coli strains, while two are Enterobacter cloacae and $P$. aeruginosa. The antimicrobial susceptibility pattern shows that, most of the isolates (83.3\%) were MDR. All the 12 isolates $(\mathbf{1 0 0 \% )}$ are resistant to Ampicillin, Cephalothin, Erythromycin, Fusidic acid, Novobiocin and Oxacillin, but sensitive to Colistin sulphate and Imipenem. Eleven isolates (91.7\%) are resistant to Chloramphenicol, Cotrimoxazole, Streptomycin, Sulphatriad and Tetracycline. Eight of the 12 isolates $(66.7 \%)$ are resistant to Ciprofloxacin and Ceftriaxone. Seven (58.3\%) are resistant to Cefotaxime, Cefuroxime and Gentamycin. Nine (75\%) are sensitive and three isolates $(25 \%)$ are resistant to Augmentin. The high resistance to these antibacterial agents in this study was due to the indiscriminate use of first-line common antibiotics like ampicillin in the study area, which is now substituted with Augmentin. Routine biochemical identification tests should always be confirmed with genotypic methods such as 165 gene sequencing, to avoid misdiagnosis, as variations do exist among some bacterial strains.
\end{abstract}

Keywords: Multidrug resistance, sequencing, $16 \mathrm{~S}$ rDNA, E. coli, Enterobacter cloacae, P. aeruginosa. Author's correspondence: myiliyasu@atbu.edu.ng 08038372210

\section{Introduction}

Proper identification of bacterial isolates is a major role of clinical diagnostic microbiology. However, conventional routine laboratory techniques are cheaper and faster in identification of most of the commonly encountered bacterial pathogens, some species are not easily identified. These methods also have shortcomings due to emergence of uncommon bacteria or those species with ambiguous metabolic properties (Munkhdelger et al., 2017). For variable, slow-growing bacteria to be identified, adequate time and standard laboratory working conditions are needed. These requirements are hardly met in our laboratories, due to ill-equipment and poor electricity supply. $16 S$ ribosomal DNA sequencing serve as a universal techniques that basically, provides 
Iliasu et al / Nig. J. Biotech. Vol. 36 Num. 2 : 158 - 166 (December 2019)

solutions to problems encountered in conventional methods, yielding authentic results, even for all types of bacteria species. 16S rDNA sequencing is useful in identification of those bacteria that cannot be easily detected phenotypically. Molecular identification of bacterial isolates from clinical specimens is more sensitive and reliable, as some significant pathogens are missed during conventional routine laboratory screening.

Resistance of bacteria to common antimicrobial agents is a great threat to public health globally. Dissemination of multidrugresistance among bacterial pathogens is commonly found to be plasmid-mediated. MDR bacterial strains have increased with the application of broad-spectrum antibacterial agents. A large number of drug-resistant genes have been reported (Li et al., 2012; Zhou et al., 2018). Multidrug resistance have negative impact on the treatment of infections caused by bacterial pathogens from both intestinal and extraintestinal sites. The multiple levels of resistance transmission make elucidation of the antimicrobial chemotherapy of Enterobacteriaceae extremely complicated (Abd El Ghany et al., 2018). This study was therefore aim at identifying bacterial isolates from clinical specimens using $16 \mathrm{~S}$ rDNA analysis and determining the multidrug resistant pattern of the isolates.

\section{Materials and Methods}

Phenotypic identification and selection of bacterial isolates

A total of twelve (12) isolates were identified based on the conventional phenotypic characteristics; Gram reaction, indole, citrate, urease, triple sugars and using analytical profile index (API 20E) test strips (Biomurieux, France). The isolates were selected for molecular studies by their ability to grow on Luria-Bertani (LB) agar medium containing $100 \mu \mathrm{g} / \mathrm{ml}$ ampicillin (Melford Laboratories, UK), as described by Sambrook and Russel (2001).

\section{Molecular identification of bacterial} isolates

Colony PCR amplification of 165 rDNA gene

The isolates were screened by $16 \mathrm{~S}$ colony PCR for bacterial species identification. A total 25 $\mu \mathrm{l}$ was used as the PCR volume, which comprised of $12.5 \mu \mathrm{l}$ master mix/My Taq polymerase, $10.5 \mu \mathrm{l}$ double distilled water, $1 \mu \mathrm{l}$ each of forward and reverse primers. From overnight culture plate, a sterile pipette tip was used to picked and transfer a single bacterial colony into the reaction tube $(0.2 \mathrm{ml}$ Eppendorf tube). The PCR was performed in G-Storm thermocycler, GS 00001 (ThermoFisher Scientific, UK). The following PCR reaction conditions was used: Initial denaturation at $94^{\circ} \mathrm{C}$ for 3minutes, then 35 cycles of denaturation $\left(95^{\circ} \mathrm{C}\right.$ for 45 seconds), annealing $\left(56^{\circ} \mathrm{C}\right.$ for 30 sec) and extension $\left(72^{\circ} \mathrm{C}\right.$ for 1 minute), with a final extension at $72^{\circ} \mathrm{C}$ for 3 mins. A molecular marker $1 \mathrm{~kb}$ DNA Hyperladder (Bioline, UK) was used to assess PCR product size. The products were separated by gel electrophoresis on $1 \%$ agarose, stained with gel red and the image were captured digitally with UV transillumination using G:Box Chemi-XX6 (Syngene, UK). The characteristics of the universal primer used for the species identification is given below.

\section{Characteristics of primer for amplification of 16S rDNA in the target bacterial species}

\begin{tabular}{|c|c|c|c|}
\hline $\begin{array}{l}\text { Gene } \\
\text { Reference }\end{array}$ & $e^{\text {Primer }}$ & Oligonucleotide sequence $\left(5^{\prime}-3^{\prime}\right)$ & Size \\
\hline 16SrDNA & $\begin{array}{l}\text { UNI F } \\
\text { UNI R }\end{array}$ & $\begin{array}{l}\text { GAGTITGATCCTGGCTCAG } \\
\text { GGACTACCAGGGTATCTAAT }\end{array}$ & $\begin{array}{l}\text { Barghouthi, } \\
\text { (2011) }\end{array}$ \\
\hline
\end{tabular}

$16 S$ rDNA purification, quantification and Sequencing

The 16S rDNA colony PCR products were clean-up using QIAquick PCR purification kit/protocol (Qiagen, UK). The clean products was quantified using Cubit 4 Fluorometer (ThermoFisher Scientific, UK). DNA purity was estimated by Lambda XLS UV Spectrophotometer, L7110191 (Perkin-Elmer
Inc., USA). UV absorbance at 260, 280, and 230 was measured according to manufacturers' instructions. The absorbance at $260 \mathrm{~nm}\left(A_{260}\right)$ and at $280 \mathrm{~nm}\left(A_{280}\right)$ for the DNA was measured to determine its purity. The quantified DNA was finally analyzed by sequencing techniques for the species identification at the Medical Research Institute, University of Dundee, UK. 
Iliasu et al / Nig. J. Biotech. Vol. 36 Num. 2 : 158 - 166 (December 2019)

Screening of isolates for multidrug resistance (MDR)

The isolates were screened for antimicrobial susceptibility pattern, multidrug resistant characteristics on Iso-sensitest agar (ISA) media (Oxoid, UK), using McFarland standard inoculum according to Kirby-Bauer disc diffusion methods as described by (Mahon et al., 2007). The following commercial discs were used: Combined discs M13/M14 rings (Mast

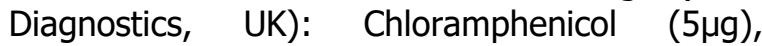
Erythromycin $(5 \mu \mathrm{g})$, Fusidic acid $(10 \mu \mathrm{g})$, Oxacillin $(5 \mu \mathrm{g})$, Novobiocin $(5 u g \mu g)$, Penicillin (1I.U), Streptomycin (10 $\mu)$, Tetracycline $(25 \mu \mathrm{g})$, and M14 rings: Ampicillin $(10 \mu \mathrm{g})$, Cephalothin $(5 \mu \mathrm{g})$, Colistin sulphate $(25 \mu \mathrm{g})$, Gentamycin $(10 \mu \mathrm{g})$, Sulphatriad $(200 \mu \mathrm{g})$, and Cotrimoxazole $(25 \mu \mathrm{g})$. Single discs (Oxoid): Amoxycillin-clavulanate/Augmentin $(30 \mu \mathrm{g})$, then Imipenem $(10 \mu \mathrm{g})$, Cefuroxime $(30 \mu \mathrm{g})$, Ceftriaxone $(30 \mu \mathrm{g})$, Cefotaxime $(30 \mu \mathrm{g})$, Ciprofloxacin $(10 \mu \mathrm{g})$ and. The diameter zone of inhibition were measured in millimetre and results were interpreted according to British society for antimicrobial chemotherapy (BSAC) guidelines, (2013). Escherichia coli NCTC 11560 and E. coli ATCC 35401 was used as positive control; while $E$. coli $\mathrm{K}-12 \mathrm{DH} 5 \mathrm{a}$ as negative control.

\section{Results and Discussion}

Antimicrobial drug resistance is a great threat for therapeutic failure in human medicine. The presence of Enterobacteria, especially multidrug resistant Escherichia coli, has increased during past decades in terms of the worldwide distribution of resistance traits and evolution of different genes. In this study, the conventional biochemical profile revealed that all the isolates are Escherichia coli. Isolates U01, U02, U03, U04, U10 and U11 were from urine specimens, S05, S06, S07, S08 and S12 from stool, while B09 was from blood. But when the API 20E test was used to identify the isolates, the results interpretation in the test manual show that three isolates were $E$. coli, Enterobacter cloacae and Kluvera sp., and no identification for the remaining nine isolates. These results indicated that conventional biochemical identification tests should always be confirmed with genotypic methods such as $16 \mathrm{~S}$ gene sequencing.

Use of 165 rDNA PCR and sequencing for bacterial species identification

The use of $16 \mathrm{~S}$ rDNA sequencing in clinical microbiology laboratories for bacterial identification, the discovery of novel bacterial genera and species, the detection of uncultivable bacteria and the diagnosis of culture-negative infections are reviewed by some studies (Esparcia et al., 2008; Sontakke et al., 2009; Barghouthi, 2011). In this study (Figure 5), 16S rDNA species identification by PCR and sequencing confirmed that all the isolates were $E$. coli with the exception of isolates U01 and S08 which were identified as Enterobacter cloacae and Pseudomonas aeruginosa respectively. A PCR product of 1500 bp was detected for all the isolates under gel documentation system. The variation in the biochemical properties of isolates in this study revealed the importance of molecular identification methods for clinical bacterial isolates in order to avoid misdiagnosis. This is due to the fact that our isolates were carefully identified using conventional biochemical tests as $E$. coli which differ in the case of API $20 \mathrm{E}$ test, but confirmed with $16 \mathrm{~S}$ rDNA sequencing.

\section{Concentration and purity level of DNA extract} After a successful DNA extraction from bacterial isolates, it is a common practice to quantify the DNA prior to using it in downstream applications. To ensure optimal performance, reactions that utilize $16 \mathrm{~S}$ rDNA or rRNA gene sequencing for bacterial species identification typically specify the required quantities of nucleic acid. In this study (Table 1 ), purity and concentration of amplified 16S rDNA PCR products from the bacterial isolates was quantified using spectroscopy and cubit fluorometry for species identification by sequencing. 


\section{$\begin{array}{lllllllllllll}M & 01 & 02 & 03 & 04 & 05 & 06 & 07 & 08 & 09 & 10 & 11 & 12\end{array}$}

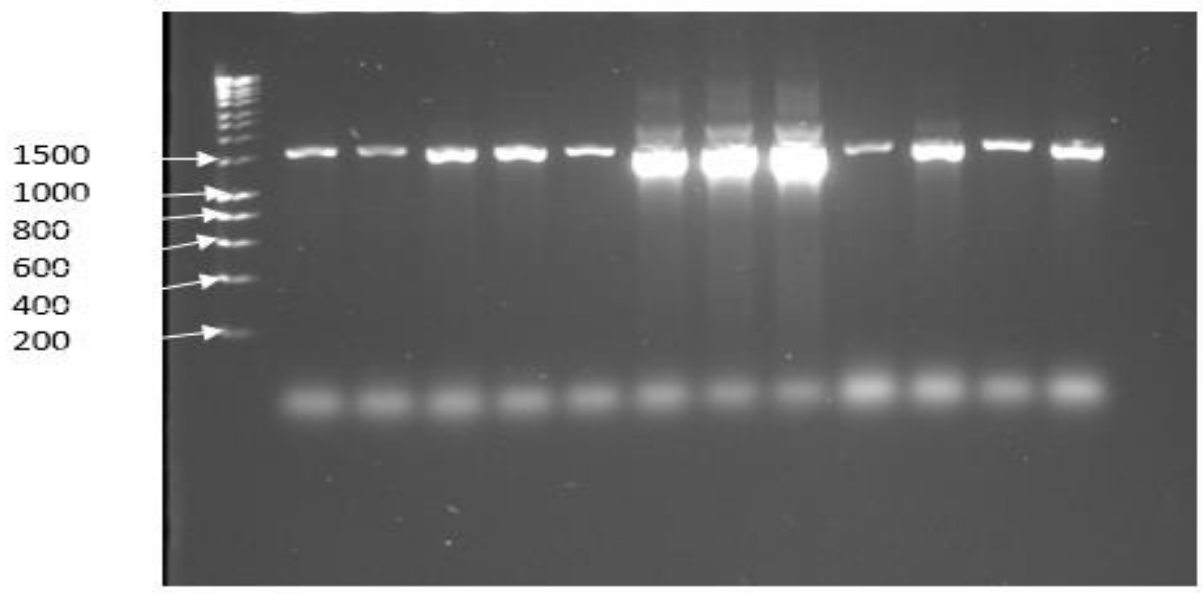

Figure 1: Agarose gel image of 165 rDNA PCR products with amplicon size of 1500 bp specific to Enterobacteriaceae, like Escherichia coli. Lane M is a DNA Hyperladder/molecular marker (Bioline, UK).

The absorbance ratio, $A_{260} / A_{280}$ was found to be between 1.4 and 2.8. This shows that the rDNA extracts from eleven isolates (92\%) is pure, as it fall within the normal range of high quality DNA (1.8-2.0) (Glasel, 1995). Isolate B09 had low purity level, but with high DNA concentration which is significant for identification. In a study by Ibrahim et al. (2014) the ratio of $A_{260} / A_{280}$ was found to be between 1.65 and 1.84, after bacterial DNA purity estimation using NanoDrop technique.

\section{Bacterial strains with 165 gene sequence producing significant alignment}

Medical diagnostic microbiology laboratories consider proper identification of pathogenic bacteria as their major tasks. This allow the scientist to differentiate between virulent and avirulent strains, as well as contaminants from mixed cultures, which paves way effective chemotherapeutic intervention, based on patient's underlying clinical condition. In this study (Table 2), the $16 \mathrm{~S}$ gene sequencing for bacterial species identification revealed that, 10 isolates had high similar gene sequence alignment with the identified $E$. coli strains, while two are Enterobacter cloacae and $P$. aeruginosa strains. Eight isolates had $16 \mathrm{~S}$ rRNA gene partial sequence and four are chromosomal DNA complete genome. Isolate U01 was an Enterobacter cloacae strain HFZ-H4 $16 \mathrm{~S}$ ribosomal RNA gene, partial sequence
(MG255304.1). Enterobacter cloacae is one of the commensal enterobacteria that is highly adaptive to different ecological niche. It is responsible for cases of disease outbreak in a hospital settings as an opportunistic pathogen (Keller et. al., 1998).

$E$. cloacae has an intrinsic resistance to ampicillin and narrow-spectrum cephalosporins and exhibits a high frequency of mutation to resistance to expanded-spectrum and broadspectrum cephalosporins. Isolate $\mathrm{U} 03$ is Escherichia fergusonii strain BI14 16S ribosomal RNA gene, partial sequence (KC986858.1) E. fergusonii is a new species in the genus Escherichia and family Enterobacteriaceae with a $64 \%$ homology to Escherichia coli after analysis by DNA hybridization techniques. The strain was isolated from cheese, some patients' gall bladder, poultry and livestock faeces. (Glover et. al., 2017).

In this study, $16 \mathrm{~S}$ gene from isolate U08 has somewhat similar sequence alignment, $89 \%$ homology with $P$. aeruginosa R7-539 16S rRNA partial sequence (JQ659890.1). Pseudomonas aeruginosa is a MDR bacteria recognized for its ubiquity, its intrinsically high antimicrobial resistance mechanisms, and its association with serious illnesses, nosocomial infections like pneumonia and sepsis. The organism was identified as an opportunistic pathogens, occurring during such disease conditions as cystic fibrosis, traumatic burns and folliculitis. 
Iliasu et al / Nig. J. Biotech. Vol. 36 Num. 2 : 158 - 166 (December 2019)

These infections can be difficult treat due to inherent resistance to antibiotics and adverse of new antimicrobial agents (Klockgether et. al., 2011).

contraindications especially with administration

Table 1: Concentration and purity level of the amplified 16S rDNA

\begin{tabular}{|c|c|c|c|c|}
\hline \multirow[t]{2}{*}{ Samples } & \multicolumn{2}{|c|}{ UV Absorbance/O.D (nm) } & \multirow{2}{*}{$\begin{array}{l}\text { Absorbance ratio } \\
\text { (purity level) }\end{array}$} & \multirow[t]{2}{*}{ DNA Conc. $(\mathrm{ng} / \mu \mathrm{l})$} \\
\hline & & 280 & & \\
\hline U01 & 0.032 & 0.020 & 1.6 & 1665 \\
\hline U02 & 0.017 & 0.006 & 2.8 & 1224 \\
\hline U03 & 0.023 & 0.012 & 1.9 & 1134 \\
\hline U04 & 0.088 & 0.017 & 2.1 & 1190 \\
\hline U06 & 0.024 & 0.013 & 1.8 & 1088 \\
\hline U10 & 0.054 & 0.023 & 1.7 & 1176 \\
\hline U11 & 0.032 & 0.010 & 2.3 & 2080 \\
\hline S05 & 0.090 & 0.015 & 2.2 & 1380 \\
\hline S07 & 0.043 & 0.012 & 2.0 & 1220 \\
\hline S08 & 0.025 & 0.009 & 2.8 & 3610 \\
\hline $\mathrm{S} 12$ & 0.058 & 0.018 & 2.0 & 5750 \\
\hline B09 & 0.088 & 0.065 & 1.4 & 1020 \\
\hline $\begin{array}{l}\text { This study } \\
\text { specime } \\
\text { mosomal } \\
\text { uence (CP } \\
\text { in WG5 is } \\
\text { in used in } \\
\text { as indicato } \\
\text { ter. The mi } \\
\text { Jalidixic acic } \\
\text { hage infecti }\end{array}$ & $\begin{array}{l}\text { Ind that } \\
\text { was } \\
\text { A, cor } \\
90.1 \text { ). } \\
\text { common } \\
\text { identifi } \\
\text { water p } \\
\text { t E. coli } \\
\text {-h increa } \\
\text { (Imamo }\end{array}$ & $\begin{array}{l}\text { tate BO9 } \\
\text { genome } \\
\text { chia coli } \\
\text { bacterial } \\
\text { f phages } \\
\text { by faecal } \\
\text { resistant } \\
\text { ceptibility } \\
\text { I., 2018). }\end{array}$ & \multicolumn{2}{|c|}{$\begin{array}{l}\text { Isolate U11 was similar to E. Coll O157:H7 } \\
\text { EDL933 with chromosomal DNA, complete } \\
\text { genome sequence (AE005174.2). It is a } \\
\text { serotype of Shigatoxin-producing E. col } \\
\text { (STEC), responsible for foodborne diseases, } \\
\text { associated with contaminated dairy products, } \\
\text { raw or semi-cooked food. The disease leads } \\
\text { to such complications as haemorrhagic } \\
\text { colitis, uremic syndrome, and death in young } \\
\text { children. (Gally \& Stevens, 2017). }\end{array}$} \\
\hline
\end{tabular}

Table 2: 16S DNA sequence producing significant alignment for species Identification

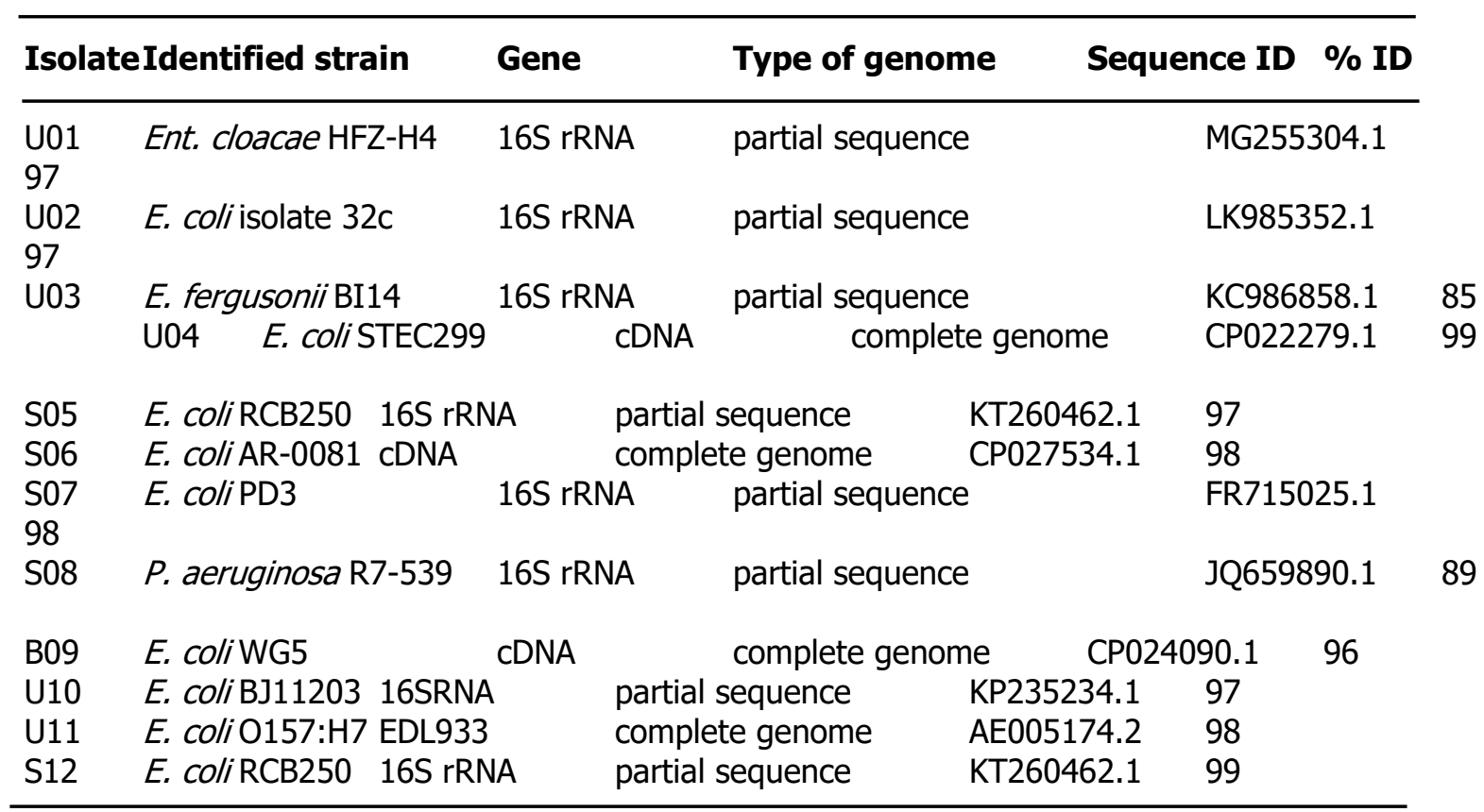

These are the highest \% ID given in the NCBI data base after blasting. The sequence ID numbers can be used to confirm. 
Iliasu et al / Nig. J. Biotech. Vol. 36 Num. 2 : 158 - 166 (December 2019)

\section{Multidrug resistant characteristics of the isolates}

Multidrug resistance in bacteria is most commonly associated with the presence of plasmids which contain one or more resistance genes, each encoding a single antibiotic resistance phenotype. In the present study, table (3) All the twelve isolates (100\%) are resistant to Ampicillin, Cephalothin, Erythromycin, Fusidic acid, Novobiocin and Oxacillin. Eleven isolates (91.7\%) are resistant to Chloramphenicol, Cotrimoxazole, Streptomycin, Sulphatriad and Tetracycline. Eight isolates $(66.7 \%)$ are resistant to Ciprofloxacin and Ceftriaxone. Seven isolates $(58.3 \%)$ are resistant to Cefotaxime, Cefuroxime and Gentamycin. Nine (9) isolates $(75 \%)$ are sensitive and three (3) isolates (25\%) are resistant to Augmentin. However, the isolates were sensitive to Colistin sulphate $(100 \%)$, Imipenem $(100 \%)$, and Augmentin (75.0\%). The E.coli isolates U03, U04, S05, S06, S07, B09, U10, U11 and S12 were sensitive to Augmentin and at least five of the isolates are also sensitive to Cefotaxime, Ceftriaxone, Cefuroxime and Gentamycin. The result showed higher resistance of the isolates to beta-lactams like ampicillin which alarms us that such drugs should no longer be used as first line of treatments in this area, as it used to be in the previous decades. These results of ampicillinresistant E.coli are congruent to the report of Farshad et. al. (2012), who found $100 \%$ resistance of their E.coli isolates to ampicillin.

A maximum resistance among $E$. coli species isolates was observed against cefpodoxime $100 \%$ by Sahu et. al. (2011). The presence of multidrug resistance in this study may be related to the dissemination of antibiotic resistance among hospital isolates. Lim et. al. (2009) observed that Escherichia coli are one of the main bacterial pathogens responsible for nosocomial infections especially in immunocompromised patients. The sensitivity of $E$. coli isolates to imipenem was also very high as reported in a previous study by Farshad et. al. (2012). This signifies that this drug can be used as the best option against Uropathogenic E. coli (UPEC).

Urinary tract infection (UTI) is one of the commonest infectious disease of human population, caused by multidrug resistant $E$. coli (MDREC) (Hadifar et. al., 2017). In this study (Table 3), isolates from various cases of UTI had the highest prevalence of MDR to commonly used antibiotics, including the third and fourth generation cephalosporins. In a study by Munkhdelger et. al. (2017) in Mangolia, the most common antibiotic resistance was to Cephalothin (85.1\%), ampicillin (78.4\%) and the least to nitrofurantoin (5.4\%) and imipenem (2\%), where $93.9 \%$ of the isolates were multidrug resistant. The antibiotic resistance profiling of UPEC strains in some reports (Lee et al., 2016) elucidates that the antimicrobial agents such as chloramphenicol, cefoxitin, Cefepime, ceftazidime might still be used in the treatment UTIs. Jan et. al. (2009) reported a high potentiality of E.coli in developing antimicrobial resistance. This study observed an emergence MDR to third-generation cephalosporins. In Nigeria, the emergence of multidrug resistant strains and its variation over the years has been increasing (Aibinu et. al., 2003).

Enterobacter cloacae is clinically important Gram-negative member of the Enterobacteriaceae and emerging pathogen, causing various nosocomial infections. In this study, the Enterobacter isolate (U01), is resistant all antibiotics tested except Colistin sulphate and Imipenem. The similar MDR pattern other isolates from this study should necessitate an investigation to determine whether a limited spread of a particular isolate existed and also to investigate the mode of resistance to new generation of beta-lactam antibiotics. Enterobacter cloacae resistant to extended-spectrum cephalosporins was reported as aetiologic agents of disease among neonates in a Greek hospital (Kartali et. al., 2002). 
Table 3: Distribution of bacterial isolates according to multidrug resistant pattern

\begin{tabular}{|c|c|c|c|c|c|c|c|c|c|c|c|c|c|c|c|}
\hline \multirow[t]{2}{*}{ Antibiotics $(\mu \mathrm{g})$} & \multicolumn{14}{|c|}{ Bacterial isolates and Zone of Inhibition ( $\mathrm{mm}$ )/Susceptibility pattern } & \multirow[b]{2}{*}{$\%$ MDR } \\
\hline & Std. ( & nm) & U01 & U02 & U03 & U04 & S05 & S06 & S07 & S08 & B09 & U10 & U11 & S12 & \\
\hline Ampicillin (10) & 15 & & $(0.0)$ & $(0.0)$ & $(0.0)$ & $(0.0)$ & $(0.0)$ & $(0.0)$ & $(0.0)$ & $(0.0)$ & $(0.0)$ & $(0.0)$ & $(0.0)$ & $(0.0)$ & $(100)$ \\
\hline Augmentin (30) & 13 & & $(0.0)$ & $(0.0)$ & $(15.3)$ & $(14.2)$ & $(0.0)$ & $(0.0)$ & $(15.7)$ & $(16.1)$ & $(17.8)$ & $(16.2)$ & (13.0) & $(23.5)$ & $(33.3)$ \\
\hline Cefotaxime (30) 20 & & $(0.0)$ & $(0.0)$ & (39.3) & $(12.8)$ & $(32.3)$ & $(0.0)$ & $(10.5)$ & $(12.0)$ & (37.8) & (36.4) & $(0.0)$ & (35.2) & (58.3) & \\
\hline Ceftriaxone (30)24 & & $(0.0)$ & $(0.0)$ & (34.1) & (12.3) & (34.2) & $(0.0)$ & $(10.0)$ & (11.6) & $(29.2)$ & (35.2) & (13.4) & (33.5) & $(66.7)$ & \\
\hline Cefuroxime (30)24 & & $(0.0)$ & $(0.0)$ & $(24.2)$ & $(0.0)$ & $(24.4)$ & $(0.0)$ & $(0.0)$ & $(0.0)$ & $(26.8)$ & (25.5) & $(0.0)$ & $(28.0)$ & $(58.3)$ & \\
\hline Cephalothin (5) & 15 & & $(0.0)$ & $(0.0)$ & $(0.0)$ & $(0.0)$ & $(0.0)$ & $(0.0)$ & $(0.0)$ & $(0.0)$ & $(0.0)$ & $(0.0)$ & $(0.0)$ & $(0.0)$ & $(100)$ \\
\hline Chloramphenicol (25) & 21 & & $(0.0)$ & $(16.4)$ & (21.3) & $(0.0)$ & $(0.0)$ & $(0.0)$ & $(0.0)$ & $(0.0)$ & $(0.0)$ & (11.8) & $(0.0)$ & $(0.0)$ & $(91.7)$ \\
\hline Ciprofloxacin (5) & 17 & & $(0.0)$ & $(0.0)$ & $(0.0)$ & $(0.0)$ & (30.8) & $(0.0)$ & $(0.0)$ & $(0.0)$ & (32.2) & (36.5) & $(0.0)$ & (26.1) & (66.7) \\
\hline Cotrimoxazole (25) & 16 & & (8.1) & $(0.0)$ & (14.2) & $(0.0)$ & $(0.0)$ & $(0.0)$ & $(0.0)$ & $(0.0)$ & $(0.0)$ & $(0.0)$ & $(0.0)$ & $(0.0)$ & $(100)$ \\
\hline Colistin sulphate (25) & 14 & & (16.5) & $(17.8)$ & (20.3) & (16.7) & $(16.2)$ & (17.3) & $(18.8)$ & $(17.2)$ & (19.1) & $(17.0)$ & $(17.2)$ & $(19.1)$ & $(0.00)$ \\
\hline Erythromycin (5) & 17 & & $(0.0)$ & $(0.0)$ & $(0.0)$ & $(0.0)$ & $(0.0)$ & $(0.0)$ & $(0.0)$ & $(0.0)$ & $(0.0)$ & $(0.0)$ & $(0.0)$ & $(0.0)$ & $(100)$ \\
\hline Fusidic acid (10) & 30 & & $(0.0)$ & $(0.0)$ & $(0.0)$ & $(0.0)$ & $(0.0)$ & $(0.0)$ & $(0.0)$ & $(0.0)$ & $(0.0)$ & $(0.0)$ & $(0.0)$ & $(0.0)$ & $(100)$ \\
\hline Gentamycin (10) & 17 & & (8.7) & $(25.6)$ & $(0.0)$ & $(0.0)$ & (20.2) & $(0.0)$ & $(0.0)$ & $(0.0)$ & (24.4) & (23.6) & (23.1) & (7.4) & (58.3) \\
\hline Imipenem (10) & 17 & & (29.3) & (33.4) & (36.1) & (32.3) & $(30.2)$ & (27.4) & (33.2) & (31.5) & (33.1) & (35.3) & (32.1) & $(30.2)$ & $(0.00)$ \\
\hline Novobiocin (5) & 16 & & $(0.0)$ & $(0.0)$ & $(0.0)$ & $(0.0)$ & $(0.0)$ & $(0.0)$ & $(0.0)$ & $(0.0)$ & $(0.0)$ & $(0.0)$ & $(0.0)$ & $(0.0)$ & $(100)$ \\
\hline Oxacillin (5) & 15 & & $(0.0)$ & $(0.0)$ & $(0.0)$ & $(0.0)$ & $(0.0)$ & $(0.0)$ & $(0.0)$ & $(0.0)$ & $(0.0)$ & $(0.0)$ & $(0.0)$ & $(0.0)$ & (100) \\
\hline Penicillin G (1I.U) & 15 & & $(0.0)$ & $(0.0)$ & $(0.0)$ & $(0.0)$ & $(0.0)$ & $(0.0)$ & $(0.0)$ & $(0.0)$ & $(0.0)$ & $(0.0)$ & $(0.0)$ & $(0.0)$ & $(100)$ \\
\hline Streptomycin (10) & 15 & & $(0.0)$ & $(0.0)$ & $(0.0)$ & $(0.0)$ & $(0.0)$ & $(0.0)$ & $(0.0)$ & $(0.0)$ & $(0.0)$ & $(0.0)$ & (18.2) & $(10.8)$ & (91.7) \\
\hline Sulphatriad (200) & 14 & & $(0.0)$ & $(0.0)$ & $(29.8)$ & $(0.0)$ & $(0.0)$ & $(0.0)$ & $(0.0)$ & $(0.0)$ & $(0.0)$ & $(0.0)$ & $(0.0)$ & $(0.0)$ & $(91.7)$ \\
\hline Tetracycline (25) & 30 & & $(0.0)$ & $(0.0)$ & (14.9) & $(0.0)$ & $(0.0)$ & $(0.0)$ & $(0.0)$ & $(0.0)$ & $(0.0)$ & $(0.0)$ & $(0.0)$ & $(0.0)$ & $(100)$ \\
\hline
\end{tabular}

Standard zone of inhibition interpreted according to BSAC guidelines, 2013


Pseudomonas aeruginosa is one of the major nosocomial and multidrug resistant (MDR) bacterial pathogen. The diseases are difficult to treat because of the limited susceptibility to antibiotics and the high frequency of an emergence of antimicrobial resistance during treatment leading to adverse contraindications (Aloush et. al., 2006). In this study, isolates S08 is also sensitive to Augmentin, Colistin sulphate and Imipenem, as in the case of $E$. coli and Enterobacter cloacae strains from this study; but are resistant to the other 17 antibiotics tested. These findings revealed the importance of beta-lactam inhibitors and carbapenems as a therapeutic options against these bacteria.

\section{Conclusion}

This study observed that poor chemotherapeutic approach and self-medication have contributed to the emergence of multidrug resistance in the area. High resistance against the commonly used antibacterials is alarming. Conventional biochemical identification tests should always be confirmed with molecular techniques such as $16 S$ gene sequencing, to ensure accurate diagnosis of bacterial infections.

\section{Reference}

Abd El Ghany, M., Sharaf, H., Al-agamy, M.H., Shibl, A., Hill-Cawthorne, G.A. and Hong, P.Y. (2018). Genomic characterization of NDM-1 and 5, and OXA-181 carbapenemases in uropathogenic Escherichia coli isolates from Riyadh, Saudi Arabia. PLoS ONE 13(8): e0201613.

Aibinu, I. E, Ohaegbulam, V. C., Adenipekun, E. A., Ogunsola, F. T., Odugbemi, T. O. and Mee, B. J. (2003). Extended-Spectrum $\beta$-Lactamase Enzymes in Clinical Isolates of Enterobacter Species from Lagos, Nigeria, J. Clin. Microbiol. 41 (5): 2197-2200.

Aloush,V., Navon-Venezia, S., Seigman-Igra, Y., Cabili, S. and Carmeli, Y. (2006.) MultidrugResistant Pseudomonas aeruginosa: Risk Factors and Clinical Impact. Antimicob. Agents and Chemother. 50 (1), 43-48.

Barghouthi, S.A (2011). A Universal Method for the Identification of Bacteria Based on General PCR Primers. Ind. J. Microbiol. 51 (4): 430 444.
Esparcia, O., Montemayor, M., Ginovart. G., Pomar,V., Soriano, G., Pericas, R. et al. (2011). Diagnostic accuracy of a $16 \mathrm{~S}$ ribosomal DNA gene-based molecular technique (RT-PCR, microarray, and sequencing) for bacterial meningitis, early-onset neonatal sepsis, and spontaneous bacterial peritonitis. Diagn. Microbiol. Infect. Dis., 69 (2): 153-160.

Fakruddin, M.D., Mohammad, R., Mazumdar, A., Chowdhury and Shahnewaj, K. (2013). A preliminary study of on virulence factors and antimicrobial resistance in Extra-intestinal pathogenic Escherichia coli (ExPEC) in Bangladesh. Ind. J. Med. Res. 137: 988-990.

Farshad, S., Ranjbar, R., Japoni, A., Hosseini, M., Anvarinejad, M. and Mohammadzadegan R. (2012) Microbial susceptibility, virulence factors, and plasmid profiles of uropathogenic Escherichia coli strains isolated from children in Jahrom, Iran. Arch. Iran. Med. 15 (5): 312-316.

Gally, D.L. and Stevens, M.P. (2017). "Microbe Profile: Escherichia coli 0157:H7 - notorious relative of the microbiologist's workhorse". Microbiol. 163 (1): 1-3.

Glover, B., Wentzel, J., Jenkins, A. and Vuuren Moritz Van (2017). The first report of Escherichia fergusonii isolated from non-human primates, in Africa. One Health, 3: $70-75$.

Hadifar, S., Moghoofei, M., Nematollahi, S., Ramazanzadeh, R., Sedighi, M., SalehiAbargouei, A. and Miri, A. (2017) Detection of virulence genes, phylogenetic group and antibiotic resistance of uropathogenic Escherichia coli in Mongolia. Jpn. J. Infect. Dis.70 (1): 1925.

Ibrahim, I.A., Al-Shwaikh, R.M. and Ismaeil, M.I. (2014). Virulence and antimicrobial resistance of Escherichia coli isolated from Tigris River and children diarrhoea. Infect. Drug Resis.7: 317322.

Imamovic, L., Misiakou, M.A., Helm E, V Muniesa, P.M. and Sommer, M.O.A (2018). Complete Genome Sequence of Escherichia coli Strain WG5. Gen. Announc.7 (3), e01511-1514.

Jan, N., Meshram, S.U. and Kulkarni, A. (2009). Plasmid profile analysis of multidrug resistant $E$. 
Iliasu et al / Nig. J. Biotech. Vol. 36 Num. 2 : 158 - 166 (December 2019)

coli isolated from UTI patients of Nagpur City, India. Rom. Biotech. Lett. 14 (5): 4635-4640.

Kartali, G., Tzelepi, E., Pournaras, S., Kontopoulou, C., Kontos, F., Sofianou, D., Maniatis, A.N. and Tsakris, A. (2002). Outbreak of Infections Caused by Enterobacter cloacae producing the Integron-Associated Betalactamase IBC-1 in a Neonatal Intensive Care Unit of a Greek Hospital, Antimicrob. Agents Chemother. 46 (5): 1577-1580.

Keller, R., Pedroso, M.Z., Ritchmann, R. and Silva, R.M. (1998). Occurrence of VirulenceAssociated Properties in Enterobacter cloacae. Infect. Immun., 66 (2): 645-649.

Klockgether, J., Cramer, N., Wiehlmann, L., Davenport, C.F. \& Tümmler, B. (2011). Pseudomonas aeruginosa genomic structure and diversity Front. Microbiol. 2, 150-158.

Lee, J.H., Subhadra, B., Son, Y.J., Kim, D.H., Park, H.S., Kim, J.M., Koo, S.H., Oh, M.H., Kim, H.J. and Choi, C.H. (2016). Phylogenetic group distributions, virulence factors and antimicrobial resistance properties of Uropathogenic Escherichia coli strains isolated from patients with urinary tract infections in South Korea. Lett. Appl. Microbiol. 62 (1): 84-90.

Li, S., Qu, Y. Hu, D. and Shi, Y. (2012). Comparison of extended spectrum betalactamases producing Escherichia coli with nonESBLS producing E.coli: drug-resistance and virulence. World J. Emerg. Med. 3 (3): 208-212.

Lim, K., Yasin, R., Yeo, C., Puthucheary, S. and Thong, K. (2009). Characterization of Multidrug Resistant ESBL-Producing Escherichia coli Isolates from Hospitals in Malaysia. J. Biomed. Biotechnol., 11(55): $10-16$.

Mahon, C., Manuselis, G and Lehman, D. (2007). Textbook of Diagnostic Microbiology, 3rd Edition, W B Saunders, Philadephia.

Munkhdelger, Y., Gunregjav, N., Dorjpurev, A., Juniichiro, N. and Sarantuya, J. (2017). Virulence factors of uropathogenic Escherichia coli of urinary tract infections and asymptomatic bacteriuria in children. J. Infect. Dev. Countr. 11(1): 51-57.
Sahu, S.K., Dalal, A.S. and Bansal, G. (2011). Detection of extended-spectrum $\beta$-lactamases in clinical isolates of $E$. coli and Klebsiella species from Udaipur, Rajasthan. Biomed. Res. 22(3): 367-373.

Sambrook, J. and Russell, D. (2001). Molecular Cloning: A Laboratory Manual (3rd ed.). Cold Springs Harbor Laboratory Press.

Sontakke, S.M., Cadenas, B., Ricardo, G., Paulo, M.P., Diniz, V.P. and Edward, B.B. (2009). Use of broad range16S rDNA PCR in clinical microbiology. J. Microbiol. Methods, 76 (3): 217225.

Zhou, Y., Zhu, X., Hou, H., Lu, Y., Yu, J., Mao, L., Mao, L. and Sun, Z. (2018) Characteristics of diarrhoeagenic Escherichia coli among children under 5 years of age with acute diarrhoea: a hospital based study. BMC Infect. Dis. 18(1). 6368. 